\title{
Metal(Loids) Bioaccessibility in Road Dust from the Surrounding Villages of an Active Mine
}

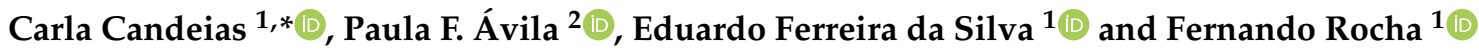 \\ 1 GeoBioTec-Geobiosciences Geotechnologies and Geoengineering Research Center, Geosciences Department, \\ Campus de Santiago, University of Aveiro, 3810-193 Aveiro, Portugal; eafsilva@ua.pt (E.F.d.S.); \\ tavares.rocha@ua.pt (F.R.) \\ 2 LNEG-National Laboratory of Energy and Geology, 4465-956 S. Mamede Infesta, Portugal; \\ paula.avila@lneg.pt \\ * Correspondence: candeias@ua.pt
}

Citation: Candeias, C.; Ávila, P.F.; Ferreira da Silva, E.; Rocha, F. Metal(Loids) Bioaccessibility in Road Dust from the Surrounding Villages of an Active Mine. Atmosphere 2021 12, 685. https://doi.org/10.3390/ atmos12060685

Academic Editor: Luca Stabile

Received: 9 April 2021

Accepted: 24 May 2021

Published: 27 May 2021

Publisher's Note: MDPI stays neutral with regard to jurisdictional claims in published maps and institutional affiliations.

Copyright: (c) 2021 by the authors. Licensee MDPI, Basel, Switzerland. This article is an open access article distributed under the terms and conditions of the Creative Commons Attribution (CC BY) license (https:/ / creativecommons.org/licenses/by/ $4.0 /)$.
Abstract: Human activities, in general, cause a significant impact on the environment and human health. The present study aims to characterize the road dust of villages located near an active mine and to assess metal(loids) bioaccessible fractions. From the collected road dust samples $(<250 \mu \mathrm{m}$ fraction), the pseudo total, gastric (G) and gastrointestinal (GI) phase (UBM assay) concentrations, mineralogical composition, enrichment factor (EF), and risk for humans were determined. The obtained results revealed that arsenic represents the highest risk to humans, with mean pseudototal values higher than the maximum reference value range. The enrichment factor pointed to As as having significant to very high enrichment in all of the villages. In addition, $\mathrm{Cd}$ presented the maximum EF values in all of the villages, and was thus classified as having a very high enrichment. Particles enriched in $\mathrm{As}, \mathrm{Ca}, \mathrm{Fe}, \mathrm{Cu}, \mathrm{Al}$, and Ti were identified by SEM-EDS in weathered agglomerates, and were linked to mine wastes and long-distance transport through both wind and/or traffic. The arsenic bioaccessibility fraction (\%BAF) presented low values in the studied samples, possibly because of the low complex solubility of Fe with adsorbed As, limiting the release of arsenic and reducing its bioaccessibility. The concentrations of bioaccessible $\mathrm{Cd}$ for the $\mathrm{G}$ and $\mathrm{GI}$ phases were within the reference range, while for $\mathrm{Cu}$, they were above and for $\mathrm{Pb}$ they were lower than the reference value range. The results show that the pseudototal fraction risk is overestimated when compared with $\mathrm{BAF} \%$; nevertheless, the total $\mathrm{G}$ and GI risks were above the carcinogenic target risk $\left(1 \times 10^{-6}\right)$ in most of the samples. The carcinogenic risk of the bioaccessible contaminants showed that As represented the higher risk for developing cancer over a lifetime, with ingestion being the main risk route.

Keywords: road dust; active mine; metal(loids); arsenic; oral bioaccessibility; human health risk

\section{Introduction}

Mining and mineral processing are known for their impact on the environment through the pollution of air, water, and soil. Large amounts of rejected materials are deposited in tailings and dams, generating dust particles enriched in potentially toxic elements (PTEs) that might disturb human health by entering the body. Road dust is considered to be a good indicator of metal(loids) contamination from diverse sources, such as industrial activities and traffic [1,2]. Metal(loids) contamination in road dust, e.g., As, Cd, $\mathrm{Cu}, \mathrm{Cr}, \mathrm{Pb}$, and $\mathrm{Hg}$, is difficult to remove, even after several years [3]. In mining areas, dust particles are dispersed (e.g., winds and traffic) and PTEs are usually adsorbed; therefore, there is the potential for these dust particles to be deposited and for contaminated soils and plants to be ingested, inhaled, and/or adhere to the skin of humans [4]. Particles less than $250 \mu \mathrm{m}$ adhere to hands, and thus may be ingested through hand to mouth behavior [5].

Several studies have taken into consideration the road dust total (or pseudo total) metal(loids) for health risk assessment (e.g., [6]), where oral bioaccessibility is defined as 
the PTE concentration. PTEs are released from their matrix in to the gastrointestinal tract, becoming potentially available for absorption [7,8], and are variable for each contaminant and location. Thus, the PTE pseudo total fraction will lead to the overestimation of the health risk assessment. Several in vitro assays have been proposed to estimate the bioaccessible fraction of pollutants, such as simplified bioaccessibility extraction tests (SBET), a conservative method that can only simulate the stomach scenario. Presently, the solubility bioaccessibility research consortium method (SBRC), physiologically-based extraction test (PBET), in vitro gastrointestinal method (IVG), and unified bioaccessibility method (UBM) are the most used in vitro gastrointestinal digestion methods because of their recognized results [9]. This study aims to characterize the road dust of four villages located in the surroundings of the Panasqueira mine, and to assess $\mathrm{As}, \mathrm{Cd}, \mathrm{Co}, \mathrm{Cr}, \mathrm{Cu}, \mathrm{Fe}$, and $\mathrm{Pb}$ bioaccessible fractions using both gastric and gastrointestinal phases through the UBM in vitro method for road dust impacted mostly by mining activities.

\section{Materials and Methods}

Study area, geology, and mining activities: Panasqueira mine (central Portugal), is considered the biggest W-Sn deposit in Western Europe. The history of this mine goes back to the end of the 19th century. Tungsten is widely used in metal-alloys, being well-known as a steel-hardener. The tungsten demand, and thus its price, rises inevitably during major armed conflicts. During the two World Wars and the Corean War, tungsten (W) extraction at the Panasqueira mine was at its highest. Detailed descriptions of the study area and geology are presented in Ávila et al. [10] and Candeias et al. [11]. Briefly, the deposit contains significant amounts of wolframite $\left((\mathrm{Fe}, \mathrm{Mn}) \mathrm{WO}_{4}\right)$; cassiterite $\left(\mathrm{SnO}_{2}\right)$; and, as a minor accessory, chalcopyrite $\left(\mathrm{CuFeS}_{2}\right)$. Arsenopyrite (FeAsS) is an abundant rejected mineral, resulting in high As concentrations being deposited in tailing and dams.

The presence of huge tailings and other debris testifies to the long history of exploitation and ore treatment operations in the Panasqueira mine (Figure 1). The piles (Rio tailing $>1.2 \mathrm{Mm}^{3}$; Barroca Grande tailing $>7.0 \mathrm{Mm}^{3}$ ) and the open-air impoundments (Rio mud dam $>0.7 \mathrm{Mm}^{3}$; Barroca Grande with two mud dams $>1.2 \mathrm{Mm}^{3}$ ) are exposed, and have been altered by chemical, mineralogical, physical, and geotechnical conditions. On the top of the Rio tailing, an arsenopyrite stockpile $\left(\sim 9400 \mathrm{~m}^{3}\right)$ was deposited and remained exposed until June 2006, when it was capped with geotextiles and layers of clay. Detailed descriptions of the mining activity history and ore treatment process are presented in Ávila et al. [10,12] and Candeias et al. [11].
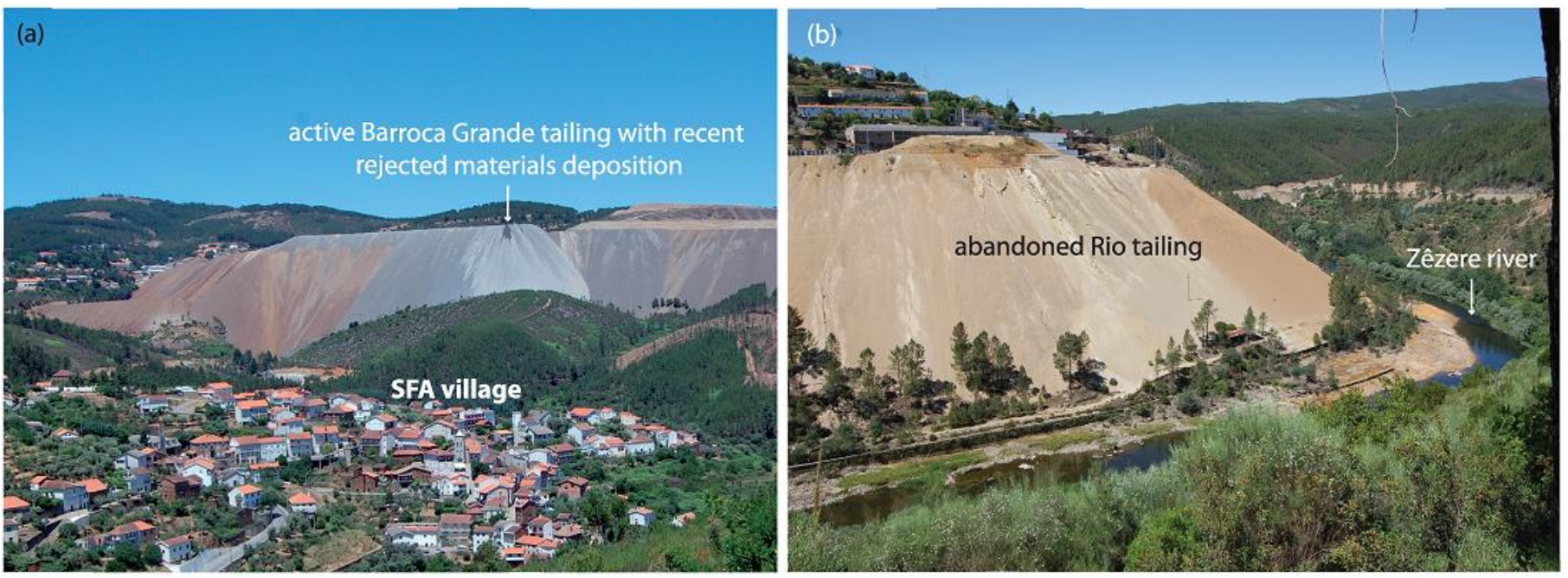

Figure 1. Partial view of the (a) active Barroca Grande tailing $\left(7 \mathrm{Mm}^{3}\right)$ and the S. Francisco de Assis (SFA) village; and the (b) abandoned Rio tailing and the Zêzere river (in Portuguese "rio") during dry season $\left(1.2 \mathrm{Mm}^{3}\right)$. 
Sample collection and preparation: The study locations selected for the collection of road dust samples were as follows: the (a) S. Francisco de Assis (SFA; $n=13$ ) and Barroca $(B ; n=7)$ villages, both located within the mining operations area (Figure 2), initially considered to be directly impacted by the mine, and the (b) Casegas $(C$; NE of the mine; $\mathrm{n}=11$ ) and Unhais-o-Velho (UV; SW of the mine; $\mathrm{n}=6$ ) villages, located on areas considered initially not to be impacted by the mine and out of the prevailing influence of wind (main direction NW-SE) [13]. The number of samples collected was considered to be representative of the population density of each small village. Each sample was collected with new and clean plastic brooms and shovels on representative roads of each village. The samples were stored in individual polyethylene bags (research grade) for further treatment and analyses. In the laboratory, samples were dried $\left(\leq 40^{\circ} \mathrm{C}\right)$ until a constant weight was attained, and were then disaggregated and wet sieved $(250 \mu \mathrm{m})$. This fraction was selected for potentially toxic elements (PTEs) assessment once a rational upper bond of the size range of ingested particles was considered to be achieved [14].

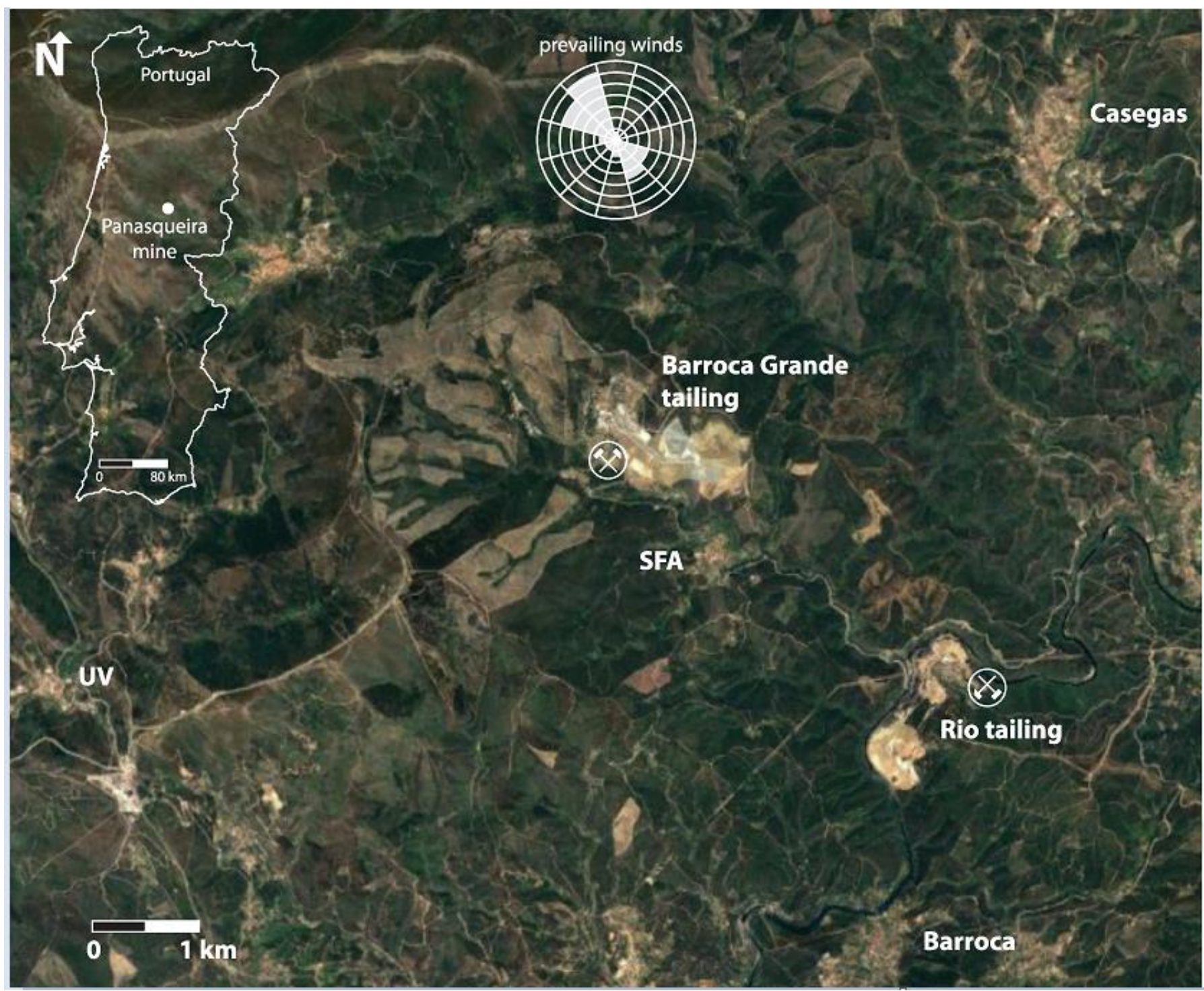

Figure 2. Panasqueira mine tailings (Barroca Grande and Rio) and the studied villages: São Francisco de Assis (SFA), Barroca, Casegas, and Unhais-o-Velho (UV). Wind rose with data collected on the top of the Panasqueira mine [13] (image adapted from Google Earth, 2021). 
Pseudo total chemical analysis: Samples with a $<250 \mu \mathrm{m}$ fraction were milled to assess the pseudo total concentration using multi-elemental analysis. A $0.5 \mathrm{~g}$ split was leached in hot $\left(95^{\circ} \mathrm{C}\right)$ aqua regia $\left(\mathrm{HCl}-\mathrm{HNO}_{3}-\mathrm{H}_{2} \mathrm{O}\right)$ for $1 \mathrm{~h}$. After dilution to $10 \mathrm{~mL}$ with demineralized water, the solutions were analyzed by inductively coupled plasma mass spectrometry (ICP-MS) for As, $\mathrm{Cd}, \mathrm{Co}, \mathrm{Cr}, \mathrm{Cu}, \mathrm{Fe}$, and $\mathrm{Pb}$ (ACME labs, Canada). The detection limits were as follows: $\mathrm{As}=0.01 \mathrm{mg} \mathrm{kg}^{-1} ; \mathrm{Cd}, \mathrm{Co}, \mathrm{Cu}$, and $\mathrm{Pb}=0.1 \mathrm{mg} \mathrm{kg}^{-1}$; $\mathrm{Cr}=1 \mathrm{mg} \mathrm{kg}^{-1}$; and $\mathrm{Fe}=100 \mathrm{mg} \mathrm{kg}^{-1}$.

In vitro oral bioaccessibility: The oral bioaccessibility of $\mathrm{As}, \mathrm{Cd}, \mathrm{Co}, \mathrm{Cr}, \mathrm{Cu}, \mathrm{Fe}$, and $\mathrm{Pb}$ was assessed using the widely employed and validated in vitro extraction method, the unified bioaccessible assay (UBM) [15]. The UBM assay was applied in the $<250 \mu \mathrm{m}$ granulometric road dust fraction. The UBM test simulated the mouth, stomach (G), and gastrointestinal (GI) compartment chemical processes by means of synthetic digestive solutions, and has been fully described in Wragg et al. [16]. The G and GI extractions were analyzed by ICP-MS for the same elements as the pseudo total analyses. The percentage of the bioaccessible contaminant (\%BAF) concentration was calculated as follows:

$$
\% \mathrm{BAF}=\frac{\text { concentration of bioaccessible element }\left(\mathrm{mg} \mathrm{kg}^{-1}\right)}{\text { concentration of total element in sample }\left(\mathrm{mg} \mathrm{kg}^{-1}\right)} \times 100
$$

X-ray diffraction (XRD): The $<250 \mu \mathrm{m}$ fraction of the eight samples that were selected based on the pseudo total concentration (see Results and discussion section) were submitted to XRD in order to identify the mineralogical constituents. The mineralogical composition (including efflorescence) was determined using a Philips X'Pert MPD machine equipped with $\mathrm{CuKa}$ radiation, graphite monochromator, automatic divergence slit, and 0.5-receiving slit. A step size of $0.05^{\circ} 2 \mathrm{q}$, a scan setting of $2-70^{\circ} 2 \mathrm{q}$, and a $10 \mathrm{~s}$ counting time were chosen.

Scanning Electron Microscopy with energy dispersive spectroscopy (SEM-EDS): The $<250 \mu \mathrm{m}$ fraction of each sample was individually placed on an aluminum holder and coated with carbon $(\mathrm{C})$ using an Emitech K950X carbon evaporator, after this it was analyzed with a HITACHI SU-70 high resolution SEM equipped with a Bruker energy dispersive spectroscopy (EDS) detector in order to identify the chemical elemental composition of the particles separately. The size and shape of each speck was also taken into consideration. The inorganic identification of insoluble particles was performed using a mix of protocols that allowed for semi-quantifing the mineralogy of each particle [17].

Granulometry: The $<250 \mu \mathrm{m}$ fractions were sieved to obtain $<106 \mu \mathrm{m}$ fractions. The particle size distribution of the road dust was determined using the X-ray sedimentation technique with a Sedigraph III Plus grain size analyzer from Micromeritics. This technique determined the relative mass distribution of the sample through particle size, and is based on two physical principles: sedimentation theory (Stokes' law) and the absorption of X-radiation (Beer-Lambert law).

The accuracy and analytical precision of the methods were determined using analyses of the reference materials and duplicate samples in each analytical set. The results were within the $95 \%$ confidence limits of the recommended values given for certified material. The relative standard deviation was between $5 \%$ and $10 \%$.

Enrichment factor (EF): applied to evaluate the degree of PTE pollution and to assess possible natural or anthropogenic sources:

$$
\mathrm{EF}=\frac{\left(\mathrm{C}_{\mathrm{i}} / \mathrm{Fe}\right)_{\text {sample }}}{\left(\mathrm{C}_{\mathrm{i}} / \mathrm{Fe}\right)_{\text {crust }}}
$$

where $C_{i}$ is the PTE pseudo total concentration in the sample and in the crust. The crustal $\mathrm{Fe}$ mean concentration was selected as a reference metal by assuming that the contribution of its anthropogenic sources could be considered negligible [18]. The EF results were classified as follows: (a) $\mathrm{EF}<2$, none to minimal enrichment; (b) $2 \leq \mathrm{EF}<5$, moderate 
enrichment; (c) $5 \leq \mathrm{EF}<20$, significant enrichment; (d) $20 \leq \mathrm{EF}<40$, very high enrichment; and (e) $E F \geq 40$, extremely high enrichment [19].

Non-carcinogenic and carcinogenic risks assessment: Human health risk assessment calculations were based on the assumption that residents, both children and adults, are directly exposed to dust through three main pathways, namely, (a) ingestion, (b) inhalation, and (c) dermal absorption of dust particles. Although particles $<10 \mu \mathrm{m}$ (PM10) are more relevant in the inhalation process, coarser sizes are likely decomposed in the gastrointestinal track. The carcinogenic and non-carcinogenic side effects for each element were computed individually, considering the reference toxicity levels for each variable, as extensively described in RAIS [20]. For each element and route (i.e., pathway), the non-cancer toxic risk was estimated by computing the hazard quotient (HQ) for systemic toxicity (i.e., noncarcinogenic risk). If $H Q>1$, this indicates that non-carcinogenic effects might occur once the exposure concentration exceeds the reference dose (RfD). Systemic toxicity is not expressed as a probability but as an evaluation, by comparing an exposure level over a period of time to a RfD derived for a similar exposure period. The cumulative noncarcinogenic hazard index (HI) corresponds to the sum of HQ for each pathway or variable. Similarly, HI > 1 indicates that non-carcinogenic effects might occur. The carcinogenic risk, or the probability of an individual developing any type of cancer over a lifetime as a result of exposure to a potential carcinogen, was estimated using the sum of the total cancer risk for the three exposure routes. A risk $>1 \times 10^{-6}$ was classified as a carcinogenic target risk, and $>1 \times 10^{-4}$ was considered unacceptable [20]. In this study, As, Cd, Co, Cu, and Fe were considered to be chronic sources of non-carcinogenic risk, and $\mathrm{As}, \mathrm{Cd}, \mathrm{Co}$, and $\mathrm{Pb}$ were considered to pose a carcinogenic risk.

\section{Results and Discussion}

The road dust pseudo total $\mathrm{As}, \mathrm{Cd}, \mathrm{Co}, \mathrm{Cr}, \mathrm{Cu}, \mathrm{Fe}$, and $\mathrm{Pb}$ concentrations are presented in Figure 3. These elements were selected because of their potential toxicity to humans and the high concentrations found, when compared to guidelines. The road dust pseudo total concentrations ranged from 16 to $3530 \mathrm{mg} \mathrm{kg}^{-1}$ (As), 0.2 to $19.8 \mathrm{mg} \mathrm{kg}^{-1}$ (Cd), 2.5 to $11.8 \mathrm{mg} \mathrm{kg}^{-1}$ (Co), 7.1 to $45 \mathrm{mg} \mathrm{kg}^{-1}$ (Cr), 12.6 to $2379 \mathrm{mg} \mathrm{kg}^{-1}$ (Cu), 8600 to $35,700 \mathrm{mg} \mathrm{kg}^{-1}(\mathrm{Fe})$, and 5.0 to $152.7 \mathrm{mg} \mathrm{kg}^{-1}(\mathrm{~Pb})$. The same elements' mean pseudo total concentrations were $404 \mathrm{mg} \mathrm{kg}^{-1}$ (As), $2.9 \mathrm{mg} \mathrm{kg}^{-1}$ (Cd), $5.2 \mathrm{mg} \mathrm{kg}^{-1}$ (Co), $16.9 \mathrm{mg} \mathrm{kg}^{-1}$ (Cr), $259 \mathrm{mg} \mathrm{kg}^{-1}(\mathrm{Cu}), 19,472 \mathrm{mg} \mathrm{kg}^{-1}(\mathrm{Fe})$, and $28.6 \mathrm{mg} \mathrm{kg}^{-1}(\mathrm{~Pb})$. An ANOVA analysis showed that there were significant differences $(p<0.05)$ between the $\mathrm{As}, \mathrm{Co}, \mathrm{Cu}, \mathrm{Fe}$, and $\mathrm{Pb}$ samples' concentrations in the four locations. The highest concentrations were found in the SFA village.

Considering the pseudo total results, As represents the highest risk to humans, with mean values 40.5 (SFA), 8.7 (Barroca), 20.6 (Casegas), and 30.7 (UV) times over the maximum reference value range $\left(R_{\mathrm{AR}}=2\right.$ to $\left.20 \mathrm{mg} \mathrm{kg}^{-1}\right)$ and the acceptable risk value $\left(\mathrm{ARV}_{\mathrm{As}}=20 \mathrm{mg} \mathrm{kg}^{-1}\right)$ [21]. In fact, the As mean and maximum values in the Casegas and UV villages were considered to not be impacted by the mining activities, and were higher than in Barroca village, located near the Rio abandoned tailing. A similar tendency occurred with the $\mathrm{Cd}, \mathrm{Co}, \mathrm{Cu}, \mathrm{Fe}$, and $\mathrm{Pb}$ pseudo total concentrations. 


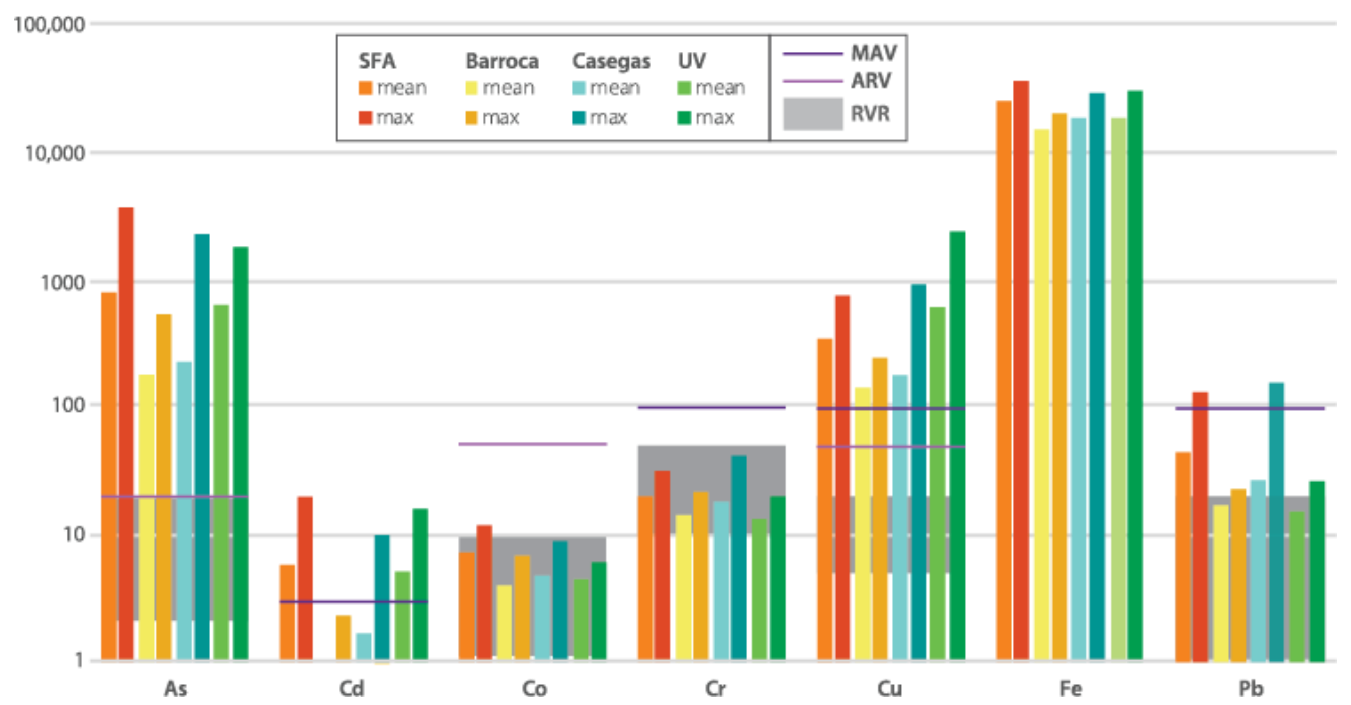

Figure 3. Mean and maximum (max) pseudo total concentrations determined in São Francisco de Assis (SFA; $n=13)$, Barroca $(n=7)$, Casegas $(n=11)$, and Unhais-o-Velho $(U V ; n=6)$ road dust samples. The reference value range (RVR) interval, acceptable risk value (ARV), and maximum acceptable value (MAV) [21] are disclosed.

An enrichment factor (EF) was applied in order to determine the PTEs road dust pollution. The results (Table 1) were particularly high for As, with a maximum value in SFA very much above the EF classification for an extremely high enrichment of 40 . In addition, the As mean value in both impacted villages was above the very high enrichment classification, suggesting an As anthropogenic source in these dusts. Casegas and UV had minimum values of 5 and 15 , respectively, suggesting significant enrichment. The variables $\mathrm{Co}$ and $\mathrm{Cr}$ both had EFs below the minimal enrichment grade, revealing a geogenic source. The SFA village had the higher $\mathrm{As}, \mathrm{Cd}$, and $\mathrm{Pb}$ maximum values, reflecting the impact of the Barroca Grande tailing located next to the village (Figure 1). Considering these results, eight representative samples (higher As EF) were selected to conduct further analyses, consisting of two samples from each of the four villages.

Table 1. Enrichment factor maximum (max), minimum (min), and mean values for the samples collected from the four villages studied (in $\mathrm{mg} \mathrm{kg}^{-1}$ ).

\begin{tabular}{|c|c|c|c|c|c|c|c|c|}
\hline \multicolumn{2}{|c|}{ EF } & As & $\mathrm{Cd}$ & Co & $\mathrm{Cr}$ & $\mathrm{Cu}$ & $\mathrm{Fe}$ & $\mathrm{Pb}$ \\
\hline \multirow{3}{*}{ SFA } & $\max$ & 699 & 77 & 1.4 & 0.5 & 40 & 11 & 24 \\
\hline & $\min$ & 29 & 3.4 & 0.8 & 0.2 & 4.9 & 3.5 & 1.4 \\
\hline & mean & 194 & 23 & 1.0 & 0.4 & 18 & 5.3 & 4.7 \\
\hline \multirow{3}{*}{ Barroca } & $\max$ & 189 & 19 & 1.2 & 0.6 & 21 & 7.5 & 3.2 \\
\hline & $\min$ & 21 & 2.0 & 0.7 & 0.3 & 4.4 & 4.6 & 1.9 \\
\hline & mean & 80 & 7.5 & 1.0 & 0.4 & 12 & 5.7 & 2.4 \\
\hline \multirow{3}{*}{ Casegas } & $\max$ & 572 & 68 & 1.3 & 0.8 & 74 & 9.3 & 19 \\
\hline & $\min$ & 5 & 0.5 & 0.6 & 0.2 & 1.4 & 3.7 & 1.2 \\
\hline & mean & 75 & 10 & 0.9 & 0.4 & 14 & 5.4 & 3.0 \\
\hline \multirow{3}{*}{ UV } & $\max$ & 494 & 63 & 1.2 & 0.7 & 119 & 15 & 3.5 \\
\hline & $\min$ & 15 & 1.7 & 0.6 & 0.2 & 8.7 & 5.2 & 0.9 \\
\hline & mean & 202 & 23 & 0.9 & 0.4 & 34 & 7.6 & 1.7 \\
\hline
\end{tabular}

Previous studies have identified diverse minerals on the tailings' and dams' rejected materials from the Panasqueira hydrothermal $\mathrm{Sn}-\mathrm{W}$ deposit, e.g., quartz $\left(\mathrm{SiO}_{2}\right)$, arsenopyrite $(\mathrm{AsFeS})$, chalcopyrite $\left(\mathrm{CuFeS}_{2}\right)$, sphalerite $((\mathrm{Zn}, \mathrm{Fe}) \mathrm{S})$, pyrrhotite $\left(\mathrm{Fe}_{(1-\mathrm{x})} \mathrm{S}\right)$, siderite $\left(\mathrm{Fe}^{2+} \mathrm{CO} 3\right)$, chlorite group minerals, and muscovite $\left(\mathrm{KAl}_{3} \mathrm{Si}_{3} \mathrm{O}_{10}(\mathrm{OH})_{2}\right)$ [22]. The XRD analysis of the $<250 \mu \mathrm{m}$ fraction samples identified quartz and clay minerals as more 
abundant, as well as scorodite $\left(\mathrm{Fe}^{3+} \mathrm{AsO}_{4} \cdot 2 \mathrm{H}_{2} \mathrm{O}\right)$, yukonite $\left(\mathrm{Ca}_{3} \mathrm{Fe}^{3+}\left(\mathrm{AsO}^{4}\right)_{2}(\mathrm{OH})_{3} \cdot 5 \mathrm{H}_{2} \mathrm{O}\right)$ and / or arseniosiderite $\left(\mathrm{Ca}_{2} \mathrm{Fe}^{3+}{ }_{3}\left(\mathrm{AsO}_{4}\right)_{3} \mathrm{O}_{2} \cdot 3 \mathrm{H}_{2} \mathrm{O}\right)$, hematite $\left(\mathrm{Fe}_{2} \mathrm{O}_{3}\right)$, clinochlore ferroan $\left(\left(\mathrm{Mg}, \mathrm{Fe}^{2+}\right)_{5} \mathrm{Al}\left(\mathrm{Si}_{3} \mathrm{Al}\right) \mathrm{O}_{10}(\mathrm{OH})_{8}\right)$, and adularia $\left(\mathrm{KAlSi}_{3} \mathrm{O}_{8}\right)$. The mineralized dust materials were weathered, and Panasqueira occurring minerals, such as arsenopyrite, sphalerite, and chalcopyrite, were mostly present as altered remains. Most of the As and metals were bound to secondary minerals such as Fe(hydr)oxides, scorodite, arseniosiderite, and/or yukonite. Secondary $\mathrm{Co}, \mathrm{Cu}$, and $\mathrm{Pb}$ mineral phases were not found in the dust, possibly as a result of poorly crystalline and/or amorphous mineral phases that could not be identified through XRD analysis.

The observation and pseudo chemical analysis by SEM-EDS (Figure 4) identified particles with a similar composition in all of the studied locations. The S. Francisco de Assis samples revealed weathered agglomerates rich in $\mathrm{As}, \mathrm{Ca}, \mathrm{Fe}, \mathrm{Cu}, \mathrm{Al}, \mathrm{Ti}$, and sharp quartz particles, suggesting a possible source from the mining waste deposited on the Barroca Grande tailing located in front of the village (Figure 1a). Other particles with a mixed composition of $\mathrm{Si}, \mathrm{Fe}, \mathrm{Al}, \mathrm{Pb}, \mathrm{K}$, and $\mathrm{Ti}$ were also found. In Barroca village, located near the abandoned Rio tailing, particles were also possibly linked to the rejected mine materials (enriched in $\mathrm{Fe}, \mathrm{Al}, \mathrm{Cu}, \mathrm{Si}$, and $\mathrm{As}$ ). As expected from the pseudo total chemical analysis results, samples from Casegas and Unhais-o-Velho also revealed particles enriched in $\mathrm{Si}, \mathrm{Al}, \mathrm{Fe}, \mathrm{Ti}, \mathrm{Cu}$, and $\mathrm{As}$, possibly linked to the long-distance transport of mine waste, both by wind or traffic. These rejected materials are transported to be used in roads and construction. The similar natural geological characteristics of the four studied locations is also a possible source.
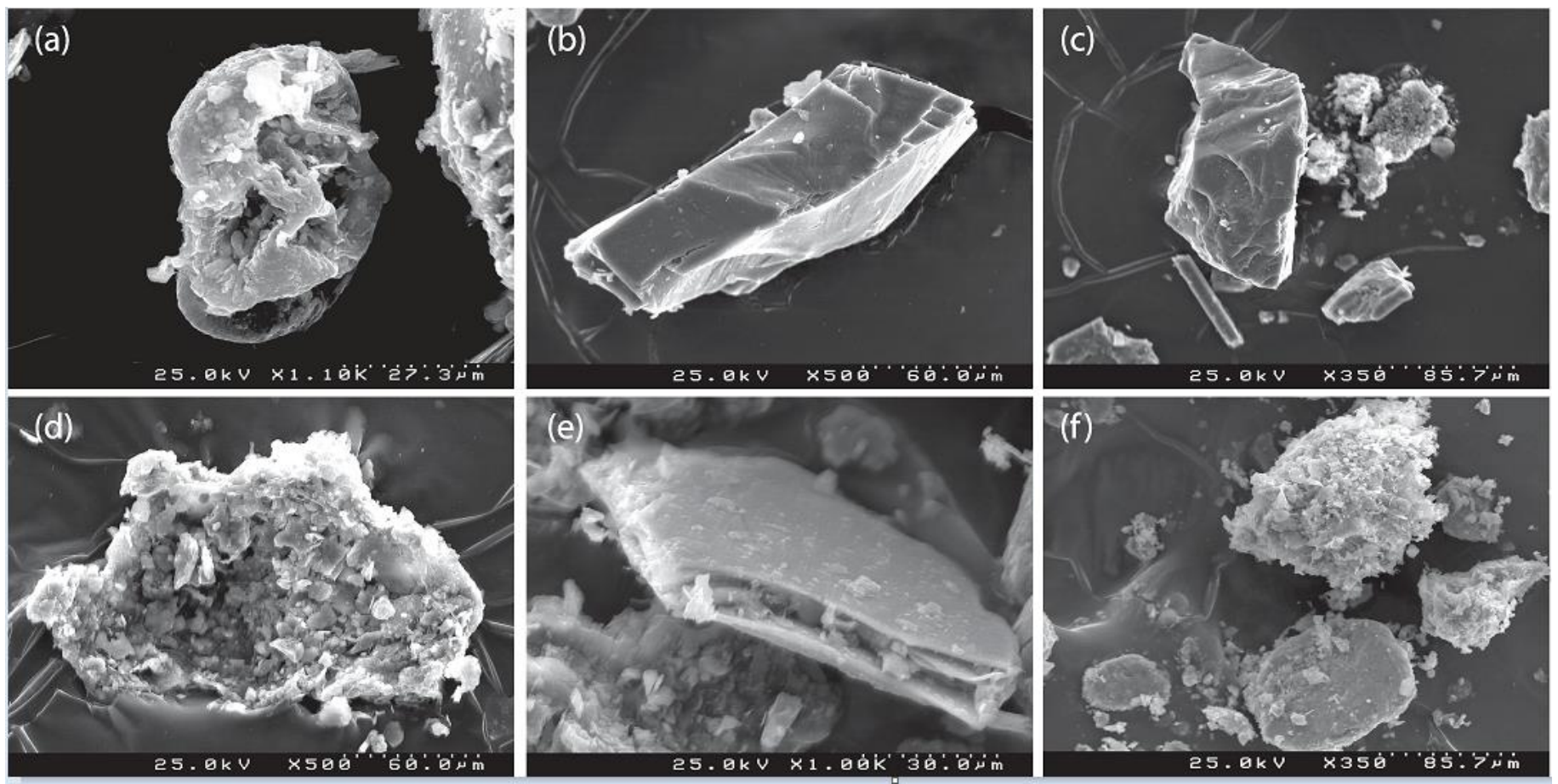

Figure 4. (a) Fe-Al-K-Si particle from Barroca; $(\mathbf{b}, \mathbf{c})$ on the center sharp quartz particle and on the left side of (c) Fe-Al-S and As-Fe-Ca rich weathered amorphous particles found in S. Francisco de Assis; (d) diverse particles mainly composed of Fe, As, and Al, as well as (e) muscovite, both images from Casegas; and (f) Si-Al-Fe-Ti-Cu-As rich particles from Unhais-o-Velho.

Qin et al. [23], among others, established a link between the increase of gastric and gastrointestinal bioaccessible extracted concentrations and the decrease in the particle grain size. Particles between 250 and $50 \mu \mathrm{m}$ ranged 43.8 to $72.0 \%$, between 50 and $10 \mu \mathrm{m}$ ranged 17.1 to $31.2 \%$ (Figure 5), and between 2 and $10 \mu \mathrm{m}$ ranged 6.1 to $16.1 \%$, and the clay fraction was the least representative fraction ( 4.8 and $13.2 \%$ ). Several studies showed that $<2 \mu \mathrm{m}$ is the most important fraction for a higher bioaccessible concentration of As and metals [24]. 


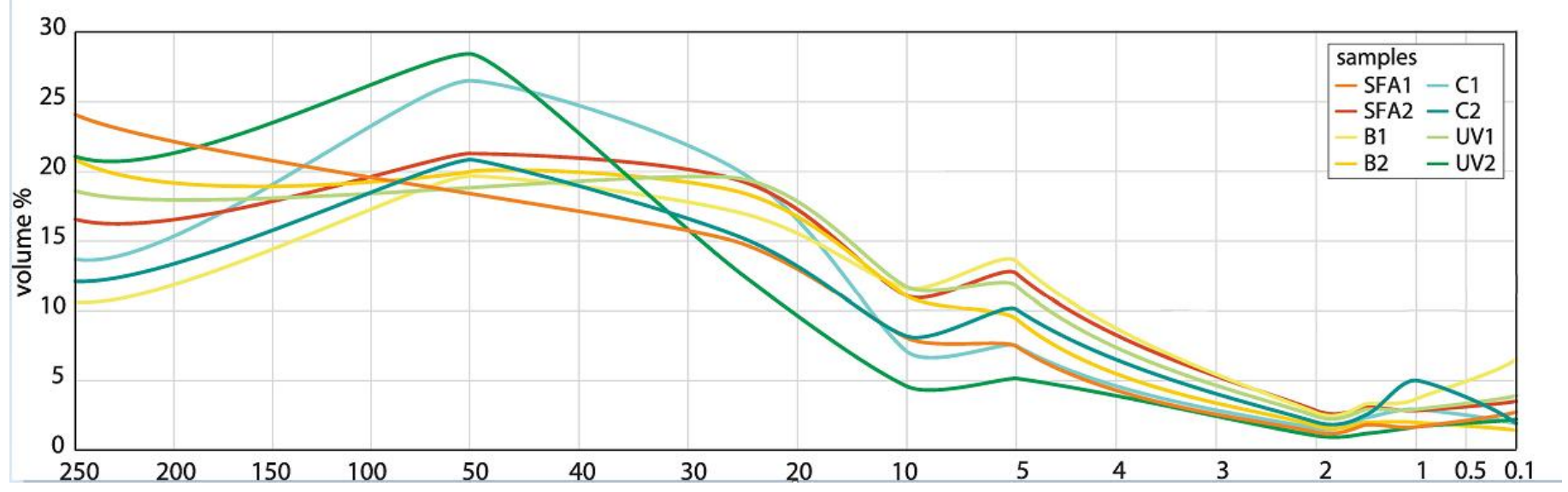

Figure 5. Size distribution (\%) of dust particles, $\varnothing<250 \mu \mathrm{m}$.

To assess $\mathrm{As}, \mathrm{Cd}, \mathrm{Co}, \mathrm{Cr}, \mathrm{Cu}, \mathrm{Fe}$, and $\mathrm{Pb}$ gastric (G) and gastrointestinal (GI) bioaccessible fractions, the UBM assay was applied to the selected samples. Previous studies (e.g., Pelfrêne and Douay [25]) suggest that As and metals are more soluble in the G fluid, because of more acidic conditions ( $\mathrm{pH} 1.2$ ) when compared with the GI phase, with a lower solubility under higher $\mathrm{pH}$ conditions ( $\mathrm{pH}$ 5.8-6.8). Although the $\mathrm{G}$ phase has a slightly higher phase bioaccessible fraction (\%BAF) when compared with GI \%BAF, a t-student test did not reveal significant differences between the two phases $(p>0.05)$. It is difficult to understand contaminant bioaccessibility in mine-impacted dusts once dissolution under gastric phases conditions is also influenced by mineralogy and particle size factors. Ore processing methodologies and environmental conditions will also impact particle behavior, e.g., through the formation of secondary minerals and morphology [26].

The As $G$ phase bioaccessible fraction $\left(\% \mathrm{BAF}_{\mathrm{AsG}}\right)$ ranged 0.13 to $5.27 \%$ and $\mathrm{GI}$ $\left(\% \mathrm{BAF}_{\mathrm{AsGI}}\right)$ ranged 0.10 to $5.64 \%$, with lower values found in $\mathrm{S}$. Francisco de Assis (Figure 6). In fact, Student's $\mathrm{t}$ test revealed that there were significant differences $(p=0.027)$ between $\% \mathrm{BAF}_{\mathrm{As}}$ in locations considered to be impacted by the mine (with lower mean concentrations) and in villages considered as not impacted, for both the G and GI phases. Similar low $\% \mathrm{BAF}_{\mathrm{As}}$ were reported in other mine impacted areas, e.g., $0.13 \%$ in Nova Scotia, Canada [27], and 0.6\% in Tavistock, England [28]. Arsenic bound to Fe might be mobilized because of the dissolution of iron compounds. A low solubility of Fe complexes could limit the release of As, reducing its bioaccessibility. Previous mineralogical studies in S. Francisco de Assis and Barroca villages [11] established a link between the tailing rejected materials and the collected dust samples, e.g., quartz $\left(\mathrm{SiO}_{2}\right)$, arsenopyrite (FeAsS), chalcopyrite $\left(\mathrm{CuFeS}_{2}\right)$, and sphalerite $(\mathrm{ZnS})$. Additionally, the tailing sulfides exposed to atmospheric conditions induced the occurrence of secondary minerals, such as scorodite $\left(\mathrm{FeAsO}_{4} \cdot 2 \mathrm{H}_{2} \mathrm{O}\right)$ and natrojarosite $\left(\mathrm{KFe}^{3+}{ }_{3}\left(\mathrm{SO}_{4}\right)_{2}(\mathrm{OH})_{6}\right)$. Different arsenic minerals showed different propensities for dissolution in low gastric and gastrointestinal $\mathrm{pH}$ conditions [27]. Antônio et al. [29] suggested that locations with the presence of a high percentage of As secondary minerals tend to have lower As \%BAF. The arsenopyrite and scorodite minerals present in the dust samples and their low solubility were consistent with the low As bioaccessible fractions, with similar percentages in the G phase and GI phases $(p>0.5)$. Maximum $\% \mathrm{BAF}_{\mathrm{As}}$ values were found in the $\mathrm{G}$ and $\mathrm{GI}$ phases of sample $\mathrm{C} 1$, collected in a village considered not impacted by the mining activities. Previous studies found that the As bioaccessible concentration decreased with the increasing particle size, being particularly evident in the 0.3- to 5- $\mu \mathrm{m}$ fraction [29]. The influence of texture and grain size on As bioaccessibility may explain $\mathrm{C} 1$ behavior, a sample with a high percentage of finer grains, a fraction composed by particles with high surface areas, a factor promoting higher bioaccessibility. 


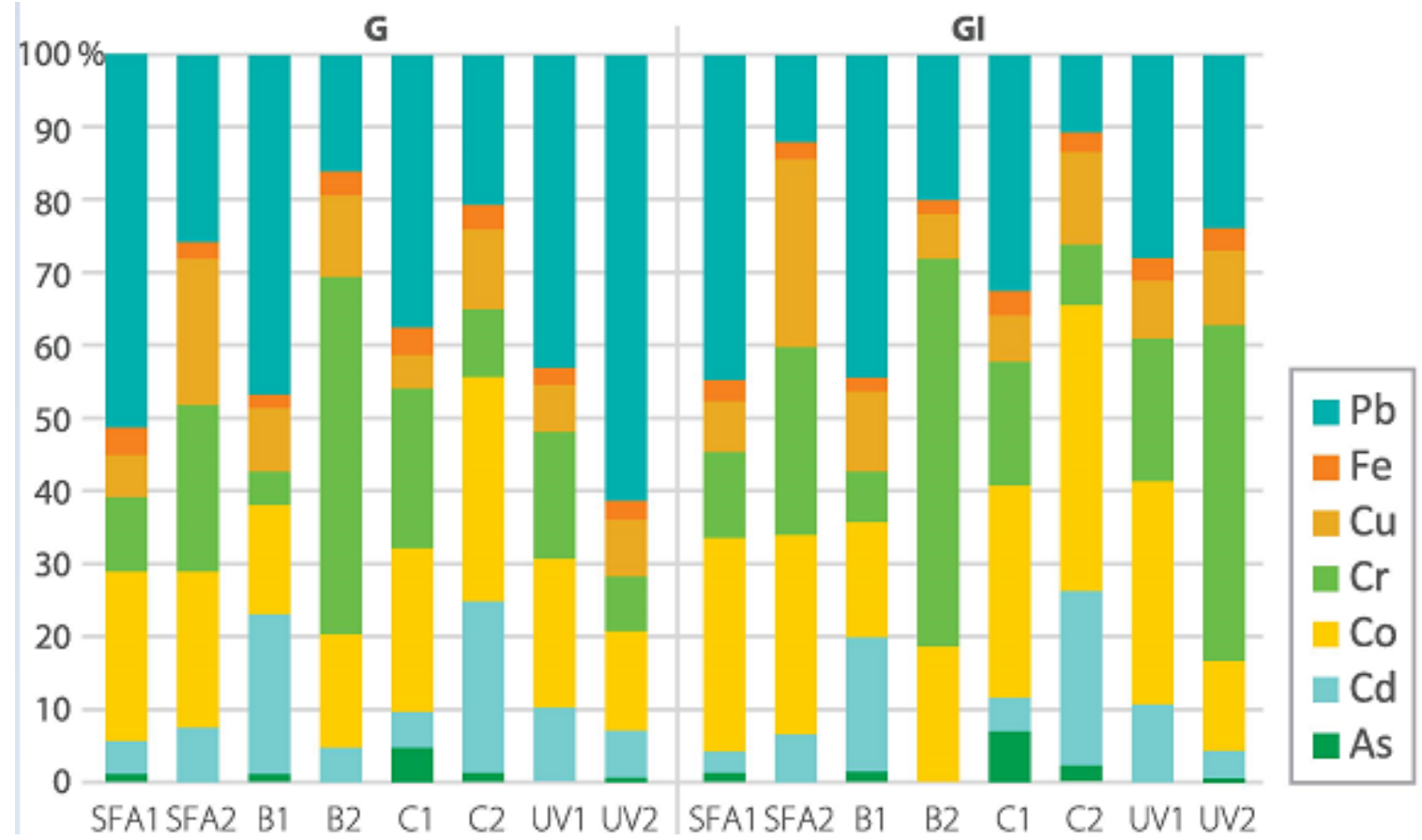

Figure 6. As, $\mathrm{Cd}, \mathrm{Co}, \mathrm{Cr}, \mathrm{Cu}, \mathrm{Fe}$, and $\mathrm{Pb}$ bioaccessible fractions (\%BAF) for both gastric $(\mathrm{G})$ and gastrointestinal (GI) phases.

From a biological point of view, Ollson et al. [30] suggested that an association with $\mathrm{Cd}$ ions might interfere with the human gastric system, leading to a reduction of As absorption. Nevertheless, $\mathrm{Cd}$ is considered a toxic metal and is nondegradable in nature, with extensive applications in different industries such as battery recycling and mining. Disorders in human health, such as bone disease, renal damages, and several forms of cancer are linked to $\mathrm{Cd}$ exposure [31]. In this study, $\% \mathrm{BAF}_{\mathrm{CdG}}$ ranged 0.52 to $37.35 \%$ and $\% \mathrm{BAF}_{\mathrm{CdGI}}$ ranged 0.07 to $21.96 \%$, showing a higher tendency to be solubilized in the gastric phase, with the maximum percentages in both phases of the $\mathrm{B} 1$ sample. Higher \% BAF values could be attributed to the presence of montmorillonite $\left((\mathrm{Na}, \mathrm{Ca})_{0.33}(\mathrm{Al}, \mathrm{Mg})_{2}\left(\mathrm{Si}_{4} \mathrm{O}_{10}\right)(\mathrm{OH})_{2} \cdot \mathrm{nH}_{2} \mathrm{O}\right)$, and the clay mineral has the possibility of increasing $\mathrm{Cd}$ solubility once it promotes $\mathrm{Cd}$ dissolution [32]. Concentrations of $\mathrm{Cd}$ bioaccessible $\mathrm{G}$ and GI phases are within the reference values range $\left(0.1-1.0 \mathrm{mg} \mathrm{kg}^{-1}\right)$, with the highest concentration found in sample $\mathrm{UV}_{\mathrm{G}}\left(1.0 \mathrm{mg} \mathrm{kg}^{-1}\right)$.

The transition element Co has complex functions in the human body, being bound to vitamin B12, with a recommended daily intake of $0.1 \mathrm{~g} /$ day in an adult's diet. Nevertheless, exposure to higher Co concentrations can cause health outcomes, such as genotoxicity and cancer [33]. The $\mathrm{Co} G$ fraction $\% \mathrm{BAF}_{\mathrm{CoG}}$ ranged 2.79 to $26.14 \%$ and the GI fraction $\% \mathrm{BAF}_{\mathrm{CoGI}}$ ranged 2.58 to $22.73 \%$, with a maximum bioavailable fraction in samples $\mathrm{B} 1(\mathrm{G})$ and UV1 (GI). Cobalt is adsorbed onto secondary Fe(III) (oxyhydr)oxides, characteristic of mining-affected environments such as Panasqueira. Chromium has been listed as a priority pollutant, with $\mathrm{Cr}^{3+}$ considered essential for a regular operation of human vascular and metabolic systems, while $\mathrm{Cr}^{6+}$ is its most dangerous form and is able to induce human health outcomes, e.g., genotoxic, carcinogenic, and mutagenic effects [34]. However, plants or animals do not bioaccumulate $\mathrm{Cr}$, with its impact being dependent on its bioaccessible fraction. In this study, $\mathrm{Cr}$ revealed a $\% \mathrm{BAF}_{\mathrm{CrG}}$ ranging 1.20 to $47.80 \%$ and $\% \mathrm{BAF} \mathrm{CrGI}_{\mathrm{CI}} 1.01$ to $77.78 \%$, with maximum bioavailable fractions in samples $\mathrm{B}_{\mathrm{G}}\left(5 \mathrm{mg} \mathrm{kg}^{-1}\right)$ and UV2 $\left(7 \mathrm{mg} \mathrm{kg}^{-1}\right)$, and both concentrations below the $10 \mathrm{mg} \mathrm{kg}^{-1}$ being defined as the lower limit of the RVR [21]. Overall, the bioaccessible results revealed a diversity in $\mathrm{Cr}$ solubility, with minimum extracted $\mathrm{G}$ and GI concentrations in sample SFA1 $\left(0.3 \mathrm{mg} \mathrm{kg}^{-1}\right)$.

The geology is a common important factor for the presence of high $\mathrm{Cu}$ concentrations. The Panasqueira deposit includes $\mathrm{Cu}$ rich minerals, such as chalcopyrite, which lead to 
high concentrations of $\mathrm{Cu}$ in old rejected materials deposited in tailings and dams as a result of less effective separation techniques used in the past [11]. In locations away from the exploration area, in the Casegas and UV villages, the $\mathrm{Cu}$ pseudo total concentration was higher than in SAF and Barroca. The $\mathrm{Cu} \% \mathrm{BAF}_{\mathrm{CuG}}$ ranged 0.60 to $14.76 \%$ and $\% \mathrm{BAF}_{\mathrm{CuGI}}$ ranged 0.61 to $19.78 \%$. Sample $\mathrm{SFA} 2_{\mathrm{GI}}$ had bioaccessible concentrations of $\mathrm{G}=60 \mathrm{mg} \mathrm{kg}^{-1}$ and $\mathrm{GI}=47 \mathrm{mg} \mathrm{kg}^{-1}$, above RVR $\left(5-20 \mathrm{mg} \mathrm{kg}^{-1}\right)$ in both extracted phases and ARV (50 mg kg$~^{-1}$ ) in the $G$ phase. The lowest extracted concentrations were found in sample SFA1 $\left(\mathrm{G}=4.4 \mathrm{mg} \mathrm{kg}^{-1}\right.$; $\left.\mathrm{GI}=4.5 \mathrm{mg} \mathrm{kg}^{-1}\right)$. Previous studies revealed a higher $\mathrm{Cu}$ bioaccessibility with a lower clay content, such as for the SFA1 sample, and the clay fraction could cause a significant retention of metals [32]. Except for SFA1 and B2 samples, the bioaccessible extracted concentrations were above the RVR.

Lead is a common environmental pollutant, with its exposure via ingestion and inhalation being a public health hazard, especially in children due to $\mathrm{Pb}$ poisoning via handto-mouth exposure. Chronic exposure to $\mathrm{Pb}$ might induce, e.g., autism, brain and kidney damage, and psychosis [35]. The bioaccessible fraction of $\mathrm{Pb}$ revealed a $\% \mathrm{BAF}_{\mathrm{PbG}}$ ranging 5.97 to $84.95 \%$ and $\% \mathrm{BAF}_{\mathrm{PbGI}} 3.95$ to $53.45 \%$. In both phases, the bioaccessible extracted concentrations were lower than RVR $\left(1-20 \mathrm{mg} \mathrm{kg}^{-1}\right)$, with minimum values in sample SFA1 (G $3.0 \mathrm{mg} \mathrm{kg}^{-1}$; GI $2.0 \mathrm{mg} \mathrm{kg}^{-1}$ ). According to Ávila et al. [10], the Barroca Grande tailing and dams had higher concentrations of $\mathrm{As}, \mathrm{Cd}, \mathrm{Cu}$, and $\mathrm{Pb}$ in the coarser rejected materials, which might explain the variable $\mathrm{Pb}$ pseudo total concentrations in the $<250 \mu \mathrm{m}$ fraction subject to UBM assay, with lower \%BAF for SFA1 and $\mathrm{C} 2$. Pb bioaccessibility is controlled by physical properties, higher amount of adsorption on clay minerals, organic matter and/or oxides, and is nevertheless difficult to predict. Furthermore, the bioaccessibility of an element depends on its chemical speciation $[24,36]$.

\section{Human Health Risk Assessment}

There are several studies suggesting that road dust contaminated with PTEs can directly impact human health via oral ingestion, inhalation, and dermal contact. Most of health risk assessment studies are based on pseudo total concentrations. Nevertheless, not all PTE concentrationd present in road dust are available to absorption, and the use of total contents would overestimate the risk compared with the use of bioaccessible contents [37].

Table 2 presents the pseudo total (PT) and bioaccessible G and GI fraction risk assessment results for arsenic. The results show that the risk represented by the PT fraction is overestimated compared with BAF. Nevertheless, the total G and GI risk is above the carcinogenic target risk $\left(1.00 \times 10^{-6}\right)$ in all of the samples, except for SFA2 and B2. Additionally, the carcinogenic risk of the BAF exposed that As represents a higher risk of developing cancer over a lifetime, with the other variables being considered negligible, and with $\mathrm{Pb}$ representing a maximum of $3.0 \%$ of the total risk for both the $\mathrm{G}$ and GI phases. In addition, the ingestion route represents a higher risk. Except for samples SFA1 and SFA2, in other samples, the dermal exposure route represents $\leq 12.0 \%$ and inhalation $\leq 0.2 \%$ for the sum of the three exposure paths. 
Table 2. Arsenic carcinogenic risk on pseudo total (PT), gastric (G) and gastrointestinal (GI) phases, taking in consideration the ingestion + inhalation + dermal exposure routes $\left(\mathrm{G}_{\text {Total }}, \mathrm{GI}_{\text {Total }}\right.$ and $\left.\mathrm{PT}_{\text {Total }}\right)$ and only ingestion route $\left(\mathrm{G}_{\text {Ing }}, \mathrm{GI}_{\text {Ing, }} \mathrm{PT}_{\text {Ing }}\right)$. In orange, values above the carcinogenic target risk $\left(>1 \times 10^{-6}\right)$ and in red considered as inadmissible $\left(>1 \times 10^{-4}\right)$.

\begin{tabular}{ccccccc}
\hline ID & $\mathbf{G}_{\text {Ing }}$ & $\mathbf{G}_{\text {Total }}$ & GI Ing $_{\text {Ing }}$ & GI $_{\text {Total }}$ & PT $_{\text {Ing }}$ & PT $_{\text {Total }}$ \\
\hline SFA1 & $1.34 \times 10^{-6}$ & $1.62 \times 10^{-6}$ & $1.19 \times 10^{-6}$ & $1.44 \times 10^{-6}$ & $8.83 \times 10^{-4}$ & $1.07 \times 10^{-3}$ \\
SFA2 & $7.18 \times 10^{-7}$ & $8.71 \times 10^{-7}$ & $5.45 \times 10^{-7}$ & $6.61 \times 10^{-7}$ & $5.61 \times 10^{-4}$ & $6.80 \times 10^{-4}$ \\
\hline B1 & $2.72 \times 10^{-6}$ & $3.30 \times 10^{-6}$ & $2.48 \times 10^{-6}$ & $3.00 \times 10^{-6}$ & $1.29 \times 10^{-4}$ & $1.56 \times 10^{-4}$ \\
B2 & $2.23 \times 10^{-7}$ & $2.70 \times 10^{-7}$ & $2.23 \times 10^{-7}$ & $2.70 \times 10^{-7}$ & $7.08 \times 10^{-5}$ & $8.59 \times 10^{-5}$ \\
\hline C1 & $8.42 \times 10^{-6}$ & $1.02 \times 10^{-5}$ & $8.92 \times 10^{-6}$ & $1.08 \times 10^{-5}$ & $1.60 \times 10^{-4}$ & $1.94 \times 10^{-4}$ \\
C2 & $4.95 \times 10^{-6}$ & $6.01 \times 10^{-6}$ & $5.20 \times 10^{-6}$ & $6.31 \times 10^{-6}$ & $5.67 \times 10^{-4}$ & $6.87 \times 10^{-4}$ \\
\hline UV1 & $1.66 \times 10^{-6}$ & $2.01 \times 10^{-6}$ & $1.88 \times 10^{-6}$ & $2.28 \times 10^{-6}$ & $4.40 \times 10^{-4}$ & $5.34 \times 10^{-4}$ \\
UV2 & $2.38 \times 10^{-6}$ & $2.88 \times 10^{-6}$ & $2.48 \times 10^{-6}$ & $3.00 \times 10^{-6}$ & $2.29 \times 10^{-4}$ & $2.78 \times 10^{-4}$ \\
\hline
\end{tabular}

Toxicity of inorganic arsenic $\left(\mathrm{As}_{\mathrm{i}}\right)$ varies with its valence state and with its physical and chemical properties. Soluble $A s_{i}$ is absorbed through the GI tract, and is primarily distributed to the liver, kidney, aorta, and skin. Nevertheless, $\mathrm{As}_{\mathrm{i}}$ can be excreted by the human body, mainly in urine, at rates as high as $80 \%$. The acute lethal dose to humans is estimated to be $\sim 0.6 \mathrm{mg} / \mathrm{kg} /$ day. Common identified symptoms of chronic As poisoning in humans are, e.g., weakness, general debility and lassitude, loss of appetite, energy, hair and weight, and mental disorders. Several studies have shown that As increases the risk of lung, skin, bladder, liver, kidney, and prostate cancer [38].

The systemic toxicity (i.e., non-carcinogenic hazard) of the $<250 \mu \mathrm{m}$ fraction bioaccessible fraction was below the target value of 1 in all of the samples in opposition to the pseudo total concentration, where As presented HI $=8.5$ in sample SFA1. Nevertheless, these dusts bioaccessible fractions do not represent a probability of non-carcinogenic effects to occur in both children and adults through ingestion, inhalation, or dermal contact.

\section{Conclusions}

The mining and beneficiation process at the Panasqueira mine produces mine waste considered responsible for the high levels of metal(loids) noticeable on the road dusts collected in four villages located on the surroundings of the mine. The pseudo total contents identified in the analyzed dust samples reflect the influence of the waste deposit materials (e.g., scorodite, yukonite, and arseniosiderite) due to long-distance transport and dispersion of mine wastes, both by wind or traffic. These dust samples' As pseudo total concentration exceed 40.5 (SFA), 8.7 (Barroca), 20.6 (Casegas), and 30.7 (UV) times the maximum reference value range $\left(\mathrm{RVR}_{\mathrm{As}}=2\right.$ to $\left.20 \mathrm{mg} \mathrm{kg}^{-1}\right)$ and the acceptable risk value $\left(\mathrm{ARV}_{\mathrm{As}}=20 \mathrm{mg} \mathrm{kg}^{-1}\right)$. Enrichment factor calculations confirm this statement, in particular for As, with a maximum value in SFA greatly above the EF classification for extremely high enrichment of 40. In addition, the SEM-EDS analysis identified particles that reveal weathered agglomerates rich in $\mathrm{As}, \mathrm{Ca}, \mathrm{Fe}, \mathrm{Cu}, \mathrm{Al}$, and Ti.

Gastric (G) and gastrointestinal (GI) phase bioaccessible fractions for As, Cd, Co, $\mathrm{Cr}, \mathrm{Cu}, \mathrm{Fe}$, and $\mathrm{Pb}$, determined by the UBM assay, reveal, as a main conclusion, that bioaccessibility extraction can vary depending on the phase extraction and sample location. The comparison between the two phases shows that the G phase has higher median concentrations than the GI phase, except for As in the areas considered not impacted by the mining activities. When compared the the pseudo total (PT) and bioaccessible $\mathrm{G}$ and GI fractions, the risk assessment for arsenic results indicates that the risk represented by the pseudo total fraction is overestimated. Nevertheless, the total G and GI risk is above the carcinogenic target risk $\left(1.00 \times 10^{-6}\right)$ in most of the samples. The carcinogenic risk of the $\mathrm{BAF}$ reveals that As represents the highest risk of developing cancer over a lifetime and the ingestion route is the one that represents the highest risk.

Regarding the link between the increase of gastric and gastrointestinal bioaccessible extracted concentrations and the decrease of particles grain size, further tests with other 
particle sizes will be performed in order to assess the bioaccessible fraction in different granulometric classes in order to understand what represents a higher risk to humans.

Author Contributions: Conceptualization, C.C.; sampling, C.C., P.F.Á., and E.F.d.S.; laboratorial activities and geochemical, mineralogical, and morphological characterization, C.C., P.F.Á. and F.R.; data treatment, C.C.; writing of original draft, C.C.; review of original draft, C.C. in collaboration with all of the co-authors. All authors have read and agreed to the published version of the manuscript.

Funding: This research received no external funding.

Institutional Review Board Statement: Not applicable.

Informed Consent Statement: Not applicable.

Data Availability Statement: Not applicable.

Acknowledgments: The authors are thankful to the Portuguese Foundation of Science and Tech-nology (FCT) and to the POHP/FSE funding program for the fellowship SFRH/BD/63349/2009. The authors are grateful for the financial support from GeoBioTec (UID/GEO/04035/2019; UIDB/04035/2020) and from FCT/MCTES through national funds, and for the co-funding by FEDER s part of the PT2020 Partnership Agreement and Compete 2020 program. The authors are also thankful to the people of the four villages that participated in this study.

Conflicts of Interest: The authors declare no conflict of interest.

\section{References}

1. Mondal, S.; Singh, G. Pollution evaluation, human health effect and tracing source of trace elements on road dust of Dhanbad, a highly polluted industrial coal belt of India. Environ. Geochem. Health 2021, 43, 2081-2103. [CrossRef]

2. Aguilera, A.; Bautista, F.; Gutiérrez-Ruiz, M.; Ceniceros-Gómez, A.E.; Cejudo, R.; Goguitchaichvili, A. Heavy metal pollution of street dust in the largest city of Mexico, sources and health risk assessment. Environ. Monit. Assess. 2021, 193, 1-16. [CrossRef]

3. Men, C.; Liu, R.; Wang, Q.; Miao, Y.; Wang, Y.; Jiao, L.; Li, L.; Cao, L.; Shen, Z.; Li, Y.; et al. Spatial-temporal characteristics, source-specific variation and uncertainty analysis of health risks associated with heavy metals in road dust in Beijing, China. Environ. Pollut. 2021, 278, 116866. [CrossRef]

4. Rainbow, P. Trace Metals in the Environment and Living Organisms. The British Isles as a Case Study; Cambridge University Press: Cambridge, UK, 2018; ISBN 978-1-108-47093-3.

5. Zheng, J.; Noller, B.; Huynh, T.; Ng, J.; Taga, R.; Diacomanolis, V.; Harris, H. How the population in Mount Isa is living with lead exposure from mining activities. Extr. Ind. Soc. 2021, 8, 123-134. [CrossRef]

6. Shahab, A.; Zhang, H.; Ullah, H.; Rashid, A.; Rad, S.; Li, J.; Xiao, H. Pollution characteristics and toxicity of potentially toxic

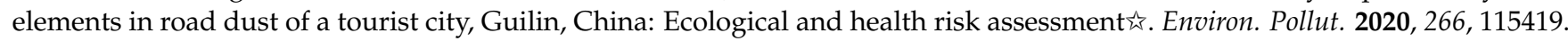
[CrossRef]

7. Eulises, C.-S.J.; González-Chávez, M.D.C.A.; Carrillo-González, R.; García-Cué, J.L.; Fernández-Reynoso, D.S.; Noerpel, M.; Scheckel, K.G. Bioaccessibility of potentially toxic elements in mine residue particles. Environ. Sci. Process. Impacts 2021, 23, 367-380. [CrossRef]

8. Zupančič, M.; Šušteršič, M.; Bavec, Š.; Gosar, M. Oral and inhalation bioaccessibility of potentially toxic elements in household dust from former $\mathrm{Hg}$ mining district, Idrija, Slovenia. Environ. Geochem. Health 2021, 1-27. [CrossRef]

9. Zhou, F.; Li, Y.; Ma, Y.; Peng, Q.; Cui, Z.; Liu, Y.; Wang, M.; Zhai, H.; Zhang, N.; Liang, D. Selenium bioaccessibility in native seleniferous soil and associated plants: Comparison between in vitro assays and chemical extraction methods. Sci. Total. Environ. 2021, 762, 143119. [CrossRef]

10. Ávila, P.F.; Da Silva, E.F.; Salgueiro, A.R.; Farinha, J.A. Geochemistry and Mineralogy of Mill Tailings Impoundments from the Panasqueira Mine (Portugal): Implications for the Surrounding Environment. Mine Water Environ. 2008, 27, 210-224. [CrossRef]

11. Candeias, C.; Melo, R.; Ávila, P.F.; da Silva, E.F.; Salgueiro, A.R.; Teixeira, J.P. Heavy metal pollution in mine-soil-plant system in S. Francisco de Assis-Panasqueira mine (Portugal). Appl. Geochem. 2014, 44, 12-26. [CrossRef]

12. Ávila, P.F.; Da Silva, E.F.; Candeias, C. Health risk assessment through consumption of vegetables rich in heavy metals: The case study of the surrounding villages from Panasqueira mine, Central Portugal. Environ. Geochem. Health 2016, 39, 565-589. [CrossRef]

13. Estanqueiro, A. (Ed.) Atlas do Potencial Eólico para Portugal Continental, V 1.0; CD-ROM; INETI: Lisboa, Portugal, 2004; ISBN 972-676-196-4. (In Portuguese)

14. Li, X.; Gao, Y.; Zhang, M.; Zhang, Y.; Zhou, M.; Peng, L.; He, A.; Zhang, X.; Yan, X.; Wang, Y.; et al. In vitro lung and gastrointestinal bioaccessibility of potentially toxic metals in $\mathrm{Pb}$-contaminated alkaline urban soil: The role of particle size fractions. Ecotoxicol. Environ. Saf. 2020, 190, 110151. [CrossRef] 
15. Soltani, N.; Keshavarzi, B.; Moore, F.; Cave, M.; Sorooshian, A.; Mahmoudi, M.R.; Golshani, R. In vitro bioaccessibility, phase partitioning, and health risk of potentially toxic elements in dust of an iron mining and industrial complex. Ecotoxicol. Environ. Saf. 2021, 212, 111972. [CrossRef]

16. Wragg, J.; Cave, M.; Basta, N.; Brandon, E.; Casteel, S.; Denys, S.; Gron, C.; Oomen, A.; Reimer, K.; Tack, K.; et al. An interlaboratory trial of the unified BARGE bioaccessibility method for arsenic, cadmium and lead in soil. Sci. Total. Environ. 2011, 409, 4016-4030. [CrossRef]

17. Wu, G.; Zhang, X.; Zhang, C.; Xu, T. Mineralogical and morphological properties of individual dust particles in ice cores from the Tibetan Plateau. J. Glaciol. 2016, 62, 46-53. [CrossRef]

18. Jose, J.; Srimuruganandam, B. Investigation of road dust characteristics and its associated health risks from an urban environment. Environ. Geochem. Health 2020, 42, 2819-2840. [CrossRef] [PubMed]

19. Rahman, M.S.; Kumar, S.; Nasiruddin, M.; Saha, N. Deciphering the origin of $\mathrm{Cu}, \mathrm{Pb}$ and Zn contamination in school dust and soil of Dhaka, a megacity in Bangladesh. Environ. Sci. Pollut. Res. 2021, 1-16. [CrossRef]

20. RAIS. The Risk Assessment Information System (RAIS); U.S. Department of Energy's Oak Ridge Operations Office (ORO): Oak Ridge, TN, USA, 2021. Available online: https:/ / rais.ornl.gov/ (accessed on 4 February 2021).

21. Sezgin, N.; Ozcan, H.; Demir, G.; Nemlioglu, S.; Bayat, C. Determination of heavy metal concentrations in street dusts in Istanbul E-5 highway. Environ. Int. 2004, 29, 979-985. [CrossRef]

22. Candeias, C.; Ávila, P.F.; Da Silva, E.F.; Teixeira, J.P. Integrated approach to assess the environmental impact of mining activities: Estimation of the spatial distribution of soil contamination (Panasqueira mining area, Central Portugal). Environ. Monit. Assess. 2015, 187, 22. [CrossRef]

23. Qin, J.; Nworie, O.E.; Lin, C. Particle size effects on bioaccessible amounts of ingestible soil-borne toxic elements. Chemosphere 2016, 159, 442-448. [CrossRef]

24. Li, Y.; Padoan, E.; Ajmone-Marsan, F. Soil particle size fraction and potentially toxic elements bioaccessibility: A review. Ecotoxicol. Environ. Saf. 2021, 209, 111806. [CrossRef]

25. Pelfrêne, A.; Douay, F. Assessment of oral and lung bioaccessibility of $\mathrm{Cd}$ and $\mathrm{Pb}$ from smelter-impacted dust. Environ. Sci. Pollut. Res. 2017, 25, 3718-3730. [CrossRef] [PubMed]

26. Ollson, C.J.; Smith, E.; Scheckel, K.; Betts, A.R.; Juhasz, A. Assessment of arsenic speciation and bioaccessibility in mine-impacted materials. J. Hazard. Mater. 2016, 313, 130-137. [CrossRef] [PubMed]

27. Meunier, L.; Walker, S.R.; Wragg, J.; Parsons, M.B.; Koch, I.; Jamieson, H.E.; Reimer, K.J. Effects of Soil Composition and Mineralogy on the Bioaccessibility of Arsenic from Tailings and Soil in Gold Mine Districts of Nova Scotia. Environ. Sci. Technol. 2010, 44, 2667-2674. [CrossRef] [PubMed]

28. Palumbo-Roe, B.; Klinck, B. Bioaccessibility of arsenic in mine waste-contaminated soils: A case study from an abandoned arsenic mine in SW England (UK). J. Environ. Sci. Health Part A 2007, 42, 1251-1261. [CrossRef]

29. Antônio, D.C.; Caldeira, C.L.; Freitas, E.T.; Delbem, I.D.; Gasparon, M.; Olusegun, S.J.; Ciminelli, V.S. Effects of aluminum and soil mineralogy on arsenic bioaccessibility. Environ. Pollut. 2021, 274, 116482. [CrossRef]

30. Ollson, C.J.; Smith, E.; Herde, P.; Juhasz, A.L. Influence of co-contaminant exposure on the absorption of arsenic, cadmium and lead. Chemosphere 2017, 168, 658-666. [CrossRef]

31. Saini, S.; Dhania, G. Cadmium as an Environmental Pollutant: Ecotoxicological Effects, Health Hazards, and Bioremediation Approaches for Its Detoxification from Contaminated Sites. In Bioremediation of Industrial Waste for Environmental Safety; Bharagava, R., Saxena, G., Eds.; Springer: Singapore, 2020. [CrossRef]

32. Mendoza, C.J.; Garrido, R.T.; Quilodrán, R.C.; Segovia, C.M.; Parada, A.J. Evaluation of the bioaccessible gastric and intestinal fractions of heavy metals in contaminated soils by means of a simple bioaccessibility extraction test. Chemosphere 2017, 176, 81-88 [CrossRef] [PubMed]

33. Leyssens, L.; Vinck, B.; Van Der Straeten, C.; Wuyts, F.; Maes, L. Cobalt toxicity in humans-A review of the potential sources and systemic health effects. Toxicology 2017, 387, 43-56. [CrossRef]

34. Laxmi, V.; Kaushik, G. Toxicity of hexavalent chromium in environment, health threats, and its bioremediation and detoxification from Tannery wastewater for environmental safety. In Bioremediation of Industrial Waste for Environmental Safety; Saxena, G., Bharagava, R., Eds.; Springer: Singapore, 2020.

35. Al-Sareji, O.; Grmasha, R.; Salman, J.; Hashim, K. Street dust contamination by heavy metals in Babylon governorate. J. Eng. Sci. Technol. 2021, 16, 455-469.

36. Doyi, I.N.; Strezov, V.; Isley, C.F.; Yazdanparast, T.; Taylor, M.P. The relevance of particle size distribution and bioaccessibility on human health risk assessment for trace elements measured in indoor dust. Sci. Total. Environ. 2020, 733, 137931. [CrossRef]

37. Han, Q.; Wang, M.; Cao, J.; Gui, C.; Liu, Y.; He, X.; He, Y.; Liu, Y. Health risk assessment and bioaccessibilities of heavy metals for children in soil and dust from urban parks and schools of Jiaozuo, China. Ecotoxicol. Environ. Saf. 2020, 191, 110157. [CrossRef]

38. Nurchi, V.M.; Djordjevic, A.B.; Crisponi, G.; Alexander, J.; Bjørklund, G.; Aaseth, J. Arsenic Toxicity: Molecular Targets and Therapeutic Agents. Biomolecules 2020, 10, 235. [CrossRef] [PubMed] 